\title{
Strengthening health systems to achieve Universal Health Coverage: Lessons from four Latin American countries.
}

\author{
Ramiro Gilardino ( $\sim$ gilardinoramiro@gmail.com ) \\ London School of Higyene and Tropical Medicine https://orcid.org/0000-0002-9238-7729 \\ Rifkin Susan B \\ London School of Hygiene and Tropical Medicine - Distance Learning Program \\ Pilar Valanzasca \\ Independent Researcher
}

Research article

Keywords: Universal Health Coverage, Latin America, Health Systems, Policy Making.

Posted Date: August 6th, 2020

DOI: https://doi.org/10.21203/rs.3.rs-48899/v1

License: (c) (1) This work is licensed under a Creative Commons Attribution 4.0 International License.

Read Full License 


\section{Abstract}

Background: During the 1990s, health systems within several Latin American countries changed to expand service coverage and reach more people. These changes are considered the antecedent of the Universal Health Coverage (UHC). Seven years after the United Nations' call for UHC, healthcare services in Argentina, Brazil, Colombia, Mexico are generally accessible and affordable. However, these countries increasingly struggle to meet their populations' growing health needs while also addressing rising health care costs. This research aims to describe measures taken by these four countries to commit by UHC, addressing their barriers and challenges.

Methods: This study examined literature review data, supplemented with survey data collected from regional stakeholders. Data were analyzed within an ad-hoc matrix.

Results: These four countries increased healthcare services coverage by strengthening their primary healthcare systems. They also expanded coverage for non-communicable diseases, provided community outreach, and increased the number of skilled healthcare workers. New pharmaceutical support programs provided access to treatments for chronic conditions at zero cost, while high-costs drugs and cancer treatments were partially guaranteed. However, these measures did not achieve full financial protection to all, leaving citizens exposed to possible catastrophic expenditures, despite increased service coverage. $\mathrm{UHC}$ is funded primarily through taxes and polling resources, and these four countries still struggle to find mechanisms that could increase pooling mechanisms capable of increasing service coverage, while reducing financial inequities among people.

Conclusions: Argentina, Brazil, Colombia, and Mexico have made progress towards UHC. Nevertheless, additional mechanisms to sustain financial protection are urgently required. The decentralization of the primary healthcare system, the development of public-private partnerships, and the implementation of progressive financing mechanisms like conditional cash transfers are potential manners to improve service delivery and financial protection contributing to effective UHC.

\section{Introduction}

According to the World Health Organization (WHO), comprehensive universal health coverage (UHC) strategies aim to guarantee "universal access to a strong and resilient people-centered health system, with primary care as its foundation." [1] Currently, 1.3 billion people lack access to effective, affordable healthcare, while an additional 1.7 billion spend at least $40 \%$ of their household income on healthcare. [2]. By expanding access to health services, covering prevention, health promotion, treatment, and rehabilitation, UHC aims to protect citizens from the potentially catastrophic financial impact associated with high-cost health care. [3]

As stated in the Sustainable Development Goals (SDG) 3.8,[3] the WHO seeks to expand UHC to one billion additional people by 2030. [4-6] To meet this goal, governments must commit to increasing public healthcare financing, while progressively increase access to essential medicines. Also, they must 
guarantee coverage to vulnerable groups, especially women and girls from the poorest wealth quintile.[7] $\mathrm{UHC}$ must also include financial protection initiatives to protect patients from the potentially catastrophic impact of large medical bills. WHO notes that policies that improve access to health services have had greater impact on expanding UHC than those that improve financial protection. [8]

During the 1990s, several countries throughout Latin America (LAC) began reforming their healthcare systems by creating frameworks to monitor improvements in quality of care[4], enhancing primary healthcare $(\mathrm{PHC})$ networks[9], decentralizing health governance, strengthening regulatory measures, and improving efficiency.[3] They also addressed the structural fragmentation that prevented health providers from making purchasing decisions. Yet these efforts have been challenged by inequitable funding and employment-based contributions that sometimes create parallel payment schemes that can lead to tiered and fragmented care. [10] As countries allocate financial resources differently, many developing economies are still debating which UHC financing mechanism may best serve their country. [11]

The purpose of this paper is to examine the approaches and potentials of implementing UHC in LAC. It examines four countries (Argentina, Brazil, Colombia, Mexico) where health services are generally accessible and affordable. However, these countries' governments increasingly struggle to meet their populations' growing health needs while also addressing rising health care costs.

This research identifies and describes measures taken to implement UHC, and discuss their barriers (political, economic, social). It concludes by making recommendations to help other LAC strengthen their health systems to fully commit to UHC.

\section{Results}

\section{Study Selection Results}

Abstracts from 411 peer-reviewed and grey literature articles were screened, with 73 undergoing full-text assessment, those who did not contain information to fill the evidence matrix were excluded. A total of 40 articles were selected for qualitative synthesis. Of these 40 articles, four focused solely on Argentina, 14 on Brazil, one on Colombia, and 13 on Mexico. The remaining eight articles examined health system processes in multiple countries (one article focused on Argentina, Brazil and Mexico; one on Brazil and Mexico; and three examined Colombia and Mexico). The three final articles reviewed processes from across Latin America. Figure 2 summarizes the study selection process.

\section{Country-specific Evidence Assessment Results}

Using the evidence assessment matrix, data were analyzed and correlated to identify UHC achievements and challenges faced by these countries during UHC implementation. Table 1 summarizes the findings from the country analysis.

\section{Healthcare service delivery}


Nearly all articles described strengthening delivery of primary care services, either by creating new care delivery models or by enhancing already functioning primary care services. $[13,14]$ Evidence suggests that some approaches reduced health inequities. [15-18]

\section{Argentina}

The Argentine healthcare system ensures all citizens have access to basic healthcare services through its tripartite of public, Obras Sociales [Social Security], and private insurance. The public health system, covers nearly 16 million people who lack any other form of coverage,[31] operates at three levels (federal, provincial, municipal) and is financed through general taxes.

After introducing Plan Federal de Salud [Federal Health Plan] in 2004, the Argentinean MOH launched Plan Nacer [Plan to Born] in 2007, providing coverage to pregnant women and children up to five years of age. [25] In 2013, the program changed its name to Plan Sumar [Plan to Add] expanding coverage to atrisk and low-income citizens through financial aid programs, such as Asignación Universal por Hijo [Universal Child Allowance] and Asignación Universal por Nacimiento [Universal Birth Allowance]. Since inception of Plan Nacer, the low birth weight mortality rates have dropped $9 \%$, while neonatal mortality has fallen $22 \%$. $[18,19]$

Table 1- Country- specific measures to commit with UHC 


\begin{tabular}{|c|c|c|c|c|}
\hline & Argentina & Brazil & Colombia & Mexico \\
\hline $\begin{array}{l}\text { althcare } \\
\text { vice } \\
\text { ivery }\end{array}$ & $\begin{array}{l}\text { SUMAR provided } \\
\text { comprehensive PHC } \\
\text { oriented to maternal } \\
\text { and child health; } \\
\text { REDES r was } \\
\text { expanded to provide } \\
\text { coverage to all } \\
\text { chronic conditions } \\
\text { for all ages at } \\
\text { PHC [19] } \\
\text { Implementation of } \\
\text { community primary } \\
\text { care physicians } \\
\text { strengthening PHC } \\
\text { with qualified staff. }\end{array}$ & $\begin{array}{l}\text { Primary care network } \\
\text { covering } 62 \% \text { of the } \\
\text { population } \\
E S F \text { introduced community } \\
\text { health workers in primary } \\
\text { care teams, increasing } \\
\text { coverage in underserved } \\
\text { areas. } \\
\text { Improvement of pre-natal } \\
\text { care and sexual and } \\
\text { reproductive health } \\
\text { programs [15-17, 20, 21] } \\
\text { Reduction in health } \\
\text { inequalities among racial } \\
\text { groups by } \\
\text { implementation of PHC. (10) }\end{array}$ & 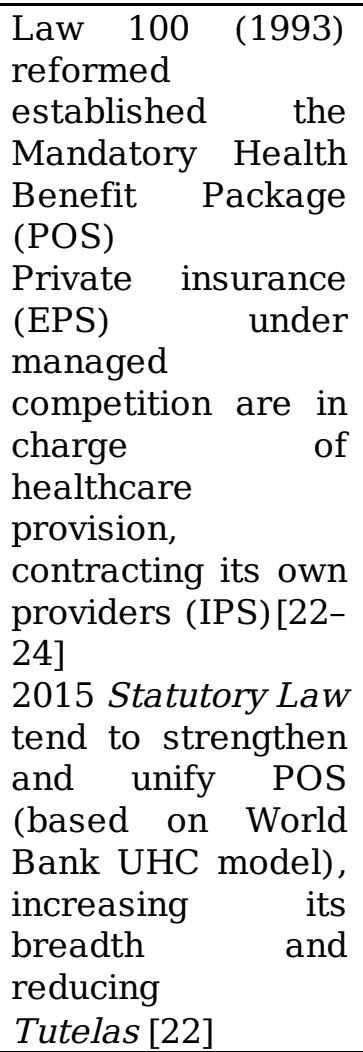 & $\begin{array}{l}\text { Social Security } \\
\text { institutions (IMSS, } \\
\text { ISSTE, PEMEX) } \\
\text { covers more than } \\
\text { 70\% of population. } \\
\text { Seguro Popular } \\
\text { (2004) and Seguro } \\
\text { Medico para la } \\
\text { nueva generacion" } \\
\text { (2007) created to } \\
\text { cover those in } \\
\text { informal sector. } \\
\text { Improvement in } \\
\text { the integral } \\
\text { coverage of } \\
\text { hypertension, Also } \\
\text { diabetes; and } \\
\text { birth control and } \\
\text { integral pregnancy } \\
\text { management for } \\
\text { 90\% of the } \\
\text { population under } \\
\text { Seguro Popular. }\end{array}$ \\
\hline $\begin{array}{l}\text { :ess to } \\
\text { dicines } \\
\text { d Health } \\
\text { ducts }\end{array}$ & $\begin{array}{l}\text { REMEDIAR provided } \\
\text { pharmaceutical } \\
\text { assistance at PHC } \\
\text { level covering } 85 \% \\
\text { of drugs for chronic } \\
\text { conditions }[19,25] \\
\text { Comprehensive care } \\
\text { programs for HIV } \\
\text { and cancer } \\
\text { guarantee } \\
\text { treatments for } \\
\text { patients w/o } \\
\text { coverage [18, 26] } \\
\text { Colorectal Cancer, } \\
\text { Cervical and Uterine } \\
\text { Cancer, Diabetes, } \\
\text { Smoke cessation } \\
\text { programs provide } \\
\text { free of charge } \\
\text { treatments [26] }\end{array}$ & $\begin{array}{l}\text { Farmacia Popular and Dose } \\
\text { Certa programs which } \\
\text { subsidized costs and } \\
\text { reduced out of pocket health } \\
\text { expenditure in treatments } \\
\text { for diabetes, hypertension, } \\
\text { asthma, and cardiovascular } \\
\text { diseases. } \\
\text { Other diseases like } \\
\text { nutritional and bleeding } \\
\text { disorders, cholera, Chagas } \\
\text { disease, dengue, } \\
\text { schistosomiasis, filariasis, } \\
\text { leprosy, HIV/AIDS, } \\
\text { influenza, leishmaniasis, } \\
\text { malaria, meningitis, } \\
\text { systemic mycoses, multiple } \\
\text { myeloma, human rabies, } \\
\text { trachoma, and tuberculosis } \\
\text { have expanded coverage. } \\
\text { National Immunization } \\
\text { program providing free } \\
\text { vaccination (11,23,36) }\end{array}$ & $\begin{array}{l}\text { Medicines and } \\
\text { health products are } \\
\text { included in the POS } \\
\text { lists managed by } \\
\text { the EPS; Large } \\
\text { proportion in out of } \\
\text { pocket expenditure } \\
\text { on essential } \\
\text { medicines were } \\
\text { seen. } \\
\text { Statutory } \\
\text { law mandated the } \\
\text { creating of a list of } \\
\text { medicines and } \\
\text { health products } \\
\text { that should be } \\
\text { removed from POS } \\
\text { due to the lack of } \\
\text { clinical benefit and } \\
\text { value for the } \\
\text { people. }\end{array}$ & 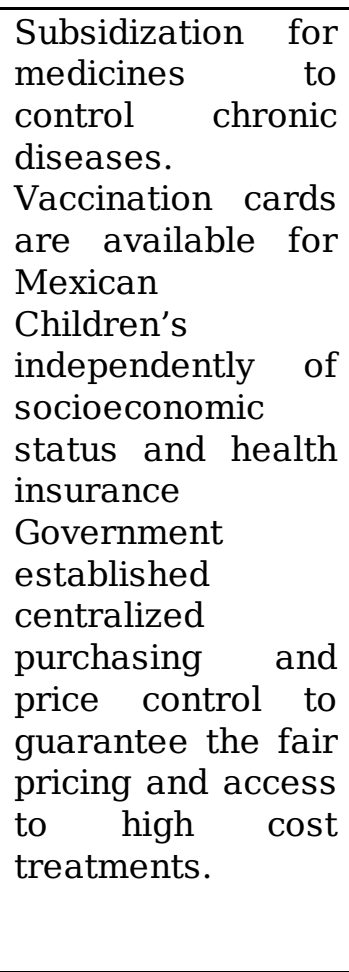 \\
\hline $\begin{array}{l}\text { vernance, } \\
\text { ancing, } \\
\text { wardship } \\
\text { l HIS }\end{array}$ & $\begin{array}{l}\text { The country lack of } \\
\text { decentralization } \\
\text { policies that } \\
\text { regulater health } \\
\text { provision from } \\
\text { central to } \\
\text { subnational levels } \\
\text { with lower primary } \\
\text { care orientation in } \\
\text { the provinces due to }\end{array}$ & $\begin{array}{l}\text { Decentralization } \\
\text { healthcare services and } \\
\text { budget } 4 \text { management } \\
\text { responsibility at municipal } \\
\text { level. [15] NGOs were } \\
\text { contracted to to provide } \\
\text { support to public health } \\
\text { services [29] } \\
\text { Lower development of } \\
\text { unified HIS in the public } \\
\text { healthcare services [17] }\end{array}$ & $\begin{array}{l}\text { Law } 100 \\
\text { established the } \\
\text { Capitation payment } \\
\text { unit a fixed amount } \\
\text { that government } \\
\text { pay to EPS per } \\
\text { insured. [22] } \\
\text { High amount of } \\
\text { people avoid } \\
\text { enrolling in POS } \\
\text { contributive level }\end{array}$ & $\begin{array}{l}\text { Implementation of } \\
\text { PPP to increase } \\
\text { coverage to NCD } \\
\text { has been cost- } \\
\text { effective. } \\
\text { Healthcare } \\
\text { facilities in SP are } \\
\text { under } \\
\text { accreditation } \\
\text { program }\end{array}$ \\
\hline
\end{tabular}




\begin{tabular}{|c|c|c|c|}
\hline $\begin{array}{l}\text { poor institutional } \\
\text { capacities [18, 19] } \\
\text { Central government } \\
\text { transferred more } \\
\text { than USD } 234 \\
\text { million to provinces } \\
\text { to fund primary } \\
\text { health strategy over } \\
S U M \mid A R[19] \\
\text { HIS is still in } \\
\text { development and } \\
\text { the country lacks of } \\
\text { connectivity across } \\
\text { the entire health } \\
{[18][19]}\end{array}$ & $\begin{array}{l}\text { Strong criticisms about } \\
\text { underfunding of } \\
\text { SUS [30] Federal spending } \\
\text { on healthcare unchanged } \\
\text { over } 15 \text { year period, slight } \\
\text { increase of 0,7\% GDP in } \\
\text { public health expenditure } \\
\text { over } 5 \text { year period [21] }\end{array}$ & $\begin{array}{l}\text { and still under } \\
\text { subsidized causing } \\
\text { effect } \\
\text { inequalities [24] } \\
\text { Labor contributions } \\
\text { are based on fixed } \\
\text { proportion of the } \\
\text { income collected by } \\
\text { the government } \\
\text { under FOSYGA [24] }\end{array}$ & $\begin{array}{l}\text { SP move towards } \\
\text { accreditation of } \\
\text { facilities, } \\
\text { investments in } \\
\text { technology and } \\
\text { qualified human } \\
\text { resources. Federal } \\
\text { and State funds } \\
\text { are granted to SP, } \\
\text { coming from tax } \\
\text { revenue and } \\
\text { household' } \\
\text { contributions }\end{array}$ \\
\hline
\end{tabular}

Enhancing the primary care network in Argentina, they introduced preventive health programs, such as those addressing sexually transmitted infections, cardiovascular disease, diabetes, and other chronic conditions. It also increased the number of deliveries attended by skilled healthcare workers, especially for those living below the poverty level. $[15,16,18,21]$ Other programs strengthened primary care by targeting public sector coverage.[26] For instance, Argentina implemented the Programa de Medicos Comunitarios [Community Doctors Program] (2004 to 2007), which applied differential payments to family medicine and general practice physicians working within primary care centers.[19]

\section{Brazil}

Brazil has a dual public/private healthcare system. The public subsector, Sistema Único de Saúde [Unified Health System] or SUS, provides free healthcare coverage for nearly $80 \%$ of citizens. Brazilian health system operations are managed primarily at the state and municipal levels, while the MOH oversees the health sector at the federal level by developing national policies and providing technical and financial assistance.

Guided by five core principles (universality, integrality, equity, decentralization, and social participation), the creation of the SUS in 1988 has been cited as "the most influential movement toward social inclusion and democratization in health." $[32,33]$ SUS provides access to free health services through programs, such as Estrategia de Saúde Familiar[Family Health Strategy] (ESF), a community-based, multidisciplinary program that assists vulnerable populations, by engaging community healthcare workers within the PHC delivery chain. $[15,17,33]$ ESF is one of the biggest community-based PHC programs in the world[15], achieving higher quality of care and user-satisfaction than traditional primary or private health care. [17] After expanding coverage of marginalized populations[15], ESF reduced mortality from both non-communicable and infectious diseases, especially infant mortality due to diarrhea and respiratory infections, while improving health outcomes for people living in remote areas. $[15,17]$ 
Brazil broadened access to PHC primarily by increasing the number of primary care physicians and nurses. [34] The Mais Médicos [More Doctors] program, established in 2013, recruited and deployed physicians to work in priority areas (e.g., remote regions with low density of healthcare workers, communities with at least $20 \%$ poverty). Due to Brazilian physicians' low interest in these roles, foreign physicians filled 500 of these positions. Later, with support from the Pan American Health Organization (PAHO), Brazil signed an agreement with the Cuban government whereby Cuba would provide the primary care doctors, increasing primary health coverage index by $12 \%$ and decreasing avoidable hospitalizations within the participating communities by 3\%. [35] Due to several concerns around this program by opposition parties, its future became unclear after President Rousseff's impeachment; however, Cuba agreed to keep providing physicians through a direct agreement with PAHO. Nonetheless, in November 2018, Cuba decided to discontinue the program soon after President Bolsonaro took office, questioning the quality of care provided by Cuban physicians.[1]

\section{Colombia}

Colombia enacted its goal for creating UHC in 1993 by initiating managed competition through largescale participation of the private sector, while also separating the purchasing functions from care provision. The Ley de Salud Universal Nro. 100 [Universal health Law 100] also stopped federal provision of health services, transferring these operations to the municipalities. Today, the majority of the population is covered through Plan Obligatorio de Salud [Mandatory Health Plan] (POS), which covers health services, medical procedures, and medicines. POS has two components: the subsidized component for those not formally employed, and the contributive component for all others.[22] As enrollment in the subsidized component grew by $24 \%$ between 2000 and 2011, access to health services expanded to more people living at the poverty level.[23, 24,36] In 2015, both components were unified under the Ley Estatutaria de Salud [Statutory Health Law], which standardized health benefits, controlled resources, and limited the number of Tutelas [lawsuits] pursuing coverage for technologies not included in the insurer's benefit packages. [22]

\section{Mexico}

Mexico's healthcare is provided through the social security system, the public health sector, and private health plans. These sectors function in parallel with little coordination between them. The public health sector is composed of the social security institutions, which cover those formally employed, and Seguro Popular [Popular Insurance], which provides coverage to those under the informal sector or at the poverty level (self-employed, unemployed, informal sector workers, those working outside the labor market, and their families), thereby achieving the main goal of UHC [14, 22, 23, 36, 37]. Established in 2004, Seguro Popular expanded its breadth of coverage when, under the 2007-2012 health reform, introduced Seguro Medico para la Nueva Generation [Health Insurance for the New Generation], providing UHC to all children born after December 2006 and those under-five-year-old who lack formal health coverage. [38] Additionally, Catalogo Universal de Servicios de Salud [Universal Catalog of Health Services] (CAUSES) 
expanded covered services to include 1,807 ICD 10 diagnostic categories, 294 surgical procedures, and treatments for 65 different catastrophic diseases. [37]

\section{Access to medicines and health products}

All four of these countries created programs to expand coverage of essential medicines, which, when paired with other interventions, $[19,25,27,28,39]$ strengthened $\mathrm{PHC}[16,19,27]$ and thereby improved treatment of non-communicable diseases. Although comprehensive oncology care and access to high cost drugs are provided in Argentina, Brazil, Colombia and Mexico, inequities still exist for people treated under the public healthcare system. $[18,27,37,39]$

\section{Argentina}

In 2002, Argentina launched Programa Remediar [Remedy Program] (REMEDIAR) as part of its national strategy to improve access to generic medicines, providing essential medicines free of charge for those enrolled in PHC [19], eventually expanding coverage to all citizens. The $\mathrm{MOH}$ provide essential drugs, such as those to treat diabetes, hypertension, asthma, and other chronic conditions, free of charge.[16, 25, 27] In 2008, REMEDIAR was integrated into different health service networks (REMEDIAR + REDES) aimed at controlling non-communicable diseases through early detection, while expanding vaccination programs for at-risk populations. [18] This program has changed its name to CUS Medicamentos [UHC Medicines], [19] and recently was revamped as REMEDIAR. [40] Argentina also established Comisión Nacional de Evaluación de Tecnologías de Salus [National Commission on Health Technology Assessment (HTA) in Argentina], or CONETEC, to provide evidence-based mechanisms to support the inclusion of new medical technologies in the national formularies. [18] Brazil

In Brazil, expanding coverage for high-cost drugs is a contentious issue, as indicated by increased lawsuits demanding coverage of high-cost drugs to treat cancer and certain rare or low prevalence diseases over the last 20 years. [28] Yet, Brazil acknowledges that drug prices constitute a significant barrier to care. SUS provides access to medicines through several programs: Programa Farmacia Popular do Brazil [Popular Pharmacy Program of Brazil], Dose Certa [Certain Dose], and Remedio em Casa [Home Remedy]. These programs have increased access to essential medicines by $20 \%$ under the SUS. [28] Brazil also provides free immunizations. [16] Finally, in 2011, Brazil established their national HTA agency, Comissão Nacional de Incorporação de Technologias No Sistema Único de Saúde [National Commission for the Incorporation of Technologies in the Unified Health System] (CONITEC)[2]. CONITEC advises $\mathrm{MOH}$ about technologies that demonstrated an additional benefit and could be incorporated in the SUS. However, the health secretary must approve all changes.

\section{Colombia}

The Statutory Law determined that the POS should establish which services are considered essential and which should be excluded from the benefits package. In 2017, resolution 330 established the procedure involving different stakeholders (including the public), to decide which technologies should be 
disinvested. Then, the $\mathrm{MOH}$ underwent a deliberative process to prioritize and create a negative POS list. [41]

In 2011, Colombia created the Instituto de Evaluacion Tecnologica en Salud [Institute of Health Technology Assessment], or IETS, as a separate public organization in charge of development of clinical guidelines and technology assessment advising the $\mathrm{MOH}$.

\section{Mexico}

Mexico's Seguro Popular provides access to low-cost medicines for chronic conditions, but on a smaller scale when compared to Argentina's Programa Remediar or Brazil's Farmacia Popular. Their enrollees also have limited access to certain high-cost treatments[14].

The Mexican government established a national commission that negotiates with the manufacturers the price of the drugs included on its "essential medicine list" [42]. These negotiation not only benefited Seguro Popular enrollees, they benefited other programs, as well, providing access to a differential price, while avoiding extensive government drugs expenditures.[43] In the case of Mexico, the price negotiation is not related to an HTA itself, it is a mechanism created by the General Health Council.

\section{Financing, Governance, Stewardship and HIS}

It is worth to remark that health expenditures vary across the four LAC as do their financing mechanisms, according to the type of fiscal policies with most using a mix of federal and state taxes. $[14,18,21,22$, $25,36,37,44,45]$ As other elements like Public-Private Partnerships (PPP), governance and HIS also do. .

\section{Argentina}

In 2015 , Argentina spent $10.2 \%$ of its GDP on healthcare, yet only $3 \%$ on public health expenditure with a per-capita health expenditure of $\$ 1390$; Although,Argentina is on top of LAC in health expenditures.[18, 25]

Due to its Federal constitution, each province owns the healthcare delivery. The government funds national programs like SUMAR by cash transfer; however, each $\mathrm{MOH}$ allocates them according to their local needs and capacities. As the country lacks regulation policies, this process is not equitable in some provinces. [21]

Argentina's HIS implementation is part of the ongoing proposal of quality implementation. $[4,18]$

\section{Brazil}

While Brazil's total healthcare spending is similar to other countries of the Organization for Economic Cooperation and Development (OECD) (roughly $9 \%$ of GDP), less than half this amount comes from public sources.[17] During the last two decades, Brazil's public health expenditure remains between $3.3 \%$ to $4.5 \%$ of its GDP. $[18,25]$ Brazil's SUS is funded through the central government, states, and municipal 
budgets, as well as tax revenue. [17] Previous articles have described how cash transfers from the central government to the states or provinces are used to implement social protection measures. $[15,25]$ One such program, Bolsa de Família [Family Grant], unifies multiple social initiatives to provide extra cash to the poorest, conditional upon school attendance and use of PHC services. [16, 29]

In Brazil, both public and private providers may deliver primary care, vaccination, pharmaceutical coverage, dental care, and tertiary care, while private organizations provide the most advanced medical care. [28, 33] PPP improves access to primary services at many municipalities. [46] However, significant controversy surrounding the recent introduction of foreign insurance companies and healthcare providers [33] to the market and the indiscriminate, not outcome-based payments for these organizations. [29, 30] Brazil has long sought societal representation in policymaking at different levels (federal, state and municipalities) through its health councils. [32] However, the lack of continuity in political will and policies to legitimize citizen involvement have contributed to structural and financial hurdles. $[17,28]$

Although the DATASUS [SUS data network] helps tracking disease registries and public expenditure to guide public health intervention, the implementation of electronic health record is delayed. [17]

\section{Colombia}

Healthcare financing in made mainly though government contributions, as well as district or municipal taxes, including gambling taxes. Also, relies on cross-subsidization across its two POS components, whereby $1.5 \%$ of payroll tax funds are transferred from the contributive regime to the subsidized one. [36] The Fondo de Solidaridad y Garantia [Solidarity and Guarantee Fund] or FOSYGA, uses a similar form of cross-subsidy, receiving funds from the insurance companies and uses it to subsidize the noncontributory system. [23] Healthcare provision is run by EPS, private insurance organizations contracted under managed competition rules to manage both POS components. However, in a country where health is considered an "economic asset", this strategy of managed competition would be considered as an "open market initiative" rather than a PPP. [23] Statutory Law mitigated asymmetries among POS components, a long-standing issue after Constitutional court passed the Sentencia T-760 [Rule T-760] Although the increasing social participation promoted by the statutory law, decision-makers perceive that citizens are not ready to be involved in these deliberative processes, as they lack understanding of health as a public good. [41]

\section{Mexico}

Mexico's public health expenses range from $2.2 \%$ to $3.0 \%$ of its GDP.[37] Seguro Popular is highlysubsidized mainly through federal and state taxes;[23] the federal government contributes with $83 \%$ of the annual cost per person, while the states provide the remaining 17\%.[44] The program saw a 13 fold increase in Federal investment from 11 million Mexican pesos in 2004 to 146 million Mexican pesos in 2013. [14] During 2017, its financial management changed to the Comision Nacional de Proteccion Social en Salud [National Commission of Social Protection in Health] and the Regimenes estatales de proteccion social en Salud [State Regimes for Social Protection in Health], two pooling mechanisms for the strategic 
purchases in the system. [14] This change led to a 9\% decrease (from $52.2 \%$ to $41.4 \%$ ) in out-of-pocket health expenditures, as well as improvement in the quality of care, and a $43 \%$ increase in coverage, adding an additional 53.5 million people in 2018. [37]

PHC is highly fragmented at the Mexican federal level, whereby of the 32 Regimenes Estatales de Protection de Salud [state regimens for health protection] (REPS) that direct the PHC implementation managing ts resources and funding, yet only 23 are partly owned by the state. [45] The Mexican government has collaborated agreements with private providers to strengthen the quality of care provided through Seguro Popular, ensuring delivery of cost-effective treatments for chronic conditions. [47]

Mexico developed an ad-hoc electronic tool to assess its health system performance, pointing out the hurdles in access to effective health coverage.[48]

\section{Survey Findings - Qualitative Assessment}

Semi-structured surveys were sent to policymakers who were involved or have a deep understanding of the UHC development in LAC. Candidates were selected according to their professional background and experience within local health system. However, the response rate was 33\% (two from Argentina, one from Brazil). Table 2 summarizes data contrasting the findings from both methods.

Table 2 - Survey findings from regional stakeholders

\begin{tabular}{|c|c|c|}
\hline Element for Analysis & $\begin{array}{c}\text { Evidence in } \\
\text { Literature } \\
\text { Review }\end{array}$ & $\begin{array}{l}\text { Framing the } \\
\text { Stakeholder } \\
\text { surveys }\end{array}$ \\
\hline \multicolumn{3}{|l|}{ Healthcare service delivery } \\
\hline Strengthening of first level of care & Available & Most Frequent \\
\hline $\begin{array}{l}\text { Are standards or guidelines for improving the quality of health services } \\
\text { delivery? }\end{array}$ & Available & Frequent \\
\hline Monitoring quality of care by indicators & Available & Frequent \\
\hline Community participation in the first level of care & Available & Frequent \\
\hline \multicolumn{3}{|l|}{ Access to Medicines and Health Products } \\
\hline $\begin{array}{l}\text { Processes for improving the availability and regulation of medicines and } \\
\text { other health technologies (medical devices, diagnostic tests) }\end{array}$ & Not Available & Some frequent \\
\hline Essential drugs provision at the first level of care & Available & Most Frequent \\
\hline Promotion of the development of generic essential medicines & Not Available & Frequent \\
\hline $\begin{array}{l}\text { Monitoring the Per capita public and private spending on pharmaceutical } \\
\text { products }\end{array}$ & Available & Frequent \\
\hline $\begin{array}{l}\text { Development of a national program for Blood donation / access to safer } \\
\text { blood products }\end{array}$ & Not Available & Frequent \\
\hline \multicolumn{3}{|l|}{ Governance, Finance, Stewardship and HIS } \\
\hline $\begin{array}{l}\text { Funding mechanisms promoting resource mobilization from the central } \\
\text { level }\end{array}$ & Available & Some Frequent \\
\hline Availability of PPP to support core elements of UHC / PHC & Available & Not Assessed \\
\hline $\begin{array}{l}\text { Tracking the average public health expenditure } \\
\text { (expressed in \% of Gross Domestic Product) }\end{array}$ & Available & Most Frequent \\
\hline $\begin{array}{l}\text { Policies to ensure the availability, equitable distribution, and quality of } \\
\text { human resources for health }\end{array}$ & Not Available & Frequent \\
\hline $\begin{array}{l}\text { Use of health information systems to support decision making / UHC } \\
\text { allocation }\end{array}$ & Available & Frequent \\
\hline
\end{tabular}


"some frequent" (10-30\% of responses), "frequent" (31-65\% of responses) and "most frequent" (66\%-100\% of responses).

\section{Discussion}

Although numerous publications analyze both the evolution of healthcare systems and adoption of UHC across Latin America, this review utilizes elements from the WHO 13th program of work Framework to examine how UHC has been incorporated into regional and country-level health systems. The information covered in this report supports the assessment, planning, and execution of those measures that enhance both service provision and financial protection mechanisms in an aim to improve access to comprehensive care, reflecting the UHC purpose. Each of the four countries have strengthened their health services coverage through UHC by establishing patient-oriented health systems that expand access to health services, especially primary care, increasing the perceived quality of care $[4,27,37]$ These LACs developed numerous country-specific measures to develop UHC through either expanded coverage of health services or through strengthened financial protections.

- Argentina achieved "nominal" UHC, meaning that people enrolled in the healthcare systems have the right to access them. [18] Currently, the country is striving towards more effective UHC, especially by improving access to quality healthcare services by introducing capitated payments transferred to the provinces that would enable expanded coverage for services included in their health benefits packages. $[4,18]$

- Brazil increased social investment due in part to Bolsa Familia. [16] In the last ten years, Brazil also expanded coverage to $62 \%$ of citizens by quadrupling the number of people covered by the ESF program.[17] To guarantee and maintain UHC targets, such as infant mortality and access to ESF, recent models of the Brazilian health system have shown that the country must increase its annual contribution by the central government to the municipalities by 3\%. [49]

- Statutory Law allowed to uniform the services covered by the POS, expanding the services ranges for those under the subsidized scheme, strengthening the health coverage and reducing the number of Tutelas.

- In 2012, Mexico also claimed to have achieved UHC, standing as another example of "nominal" UHC. [22]

UHC initiatives in these four LAC have been faced with challenges surrounding the lack of strong financial protection measures and inadequate governance mechanisms which continue to put many people at risk of catastrophic health expenditures. There is still debate surrounding the ideal financing mechanisms for UHC in low to middle-income countries (LMICs). These countries face challenges stemming from uneven tax collections and the increase in out-of-pocket expenditure [11]. Also, they operate without clear guide regarding tax funding apart from the recommendation to allocate $5 \%$ of the gross domestic product to healthcare. Challenges faced by these countries include: 
- Argentina metrics showed that even with strong financial incentives and an increase in the pooling of funds, unmet healthcare needs persist, mainly in provinces that suffer a lack of health providers, outdated health information systems, and low institutional capacity. The fragmentation in healthcare funding has led to ineffective funding policies at both the state and sub-national level. Most of these health coverage initiatives rely on the external funding, meaning these are controlled by the $\mathrm{MOH}$ or the Ministry of Finance rather than each Argentinian province. $[18,19,46]$ Health governance issues must be resolved in order to ensure access to quality health systems; financial readjustments are insufficient, as emphasized by Uribe-Gomez. [22]

- Brazil's SUS continues to be underfunded as federal health funding stagnate with public health spending increasing only $3.2 \%$ over the last 10 years.[21] SUS receives only $46 \%$ of the available funds slated for public health. [30] This has led to an increase in patient cost-sharing (e.g., out-ofpocket expenditures) for persons in the lower economic strata, as well as nearly 400,000 lawsuits related to insufficient health coverage. [50]. Two studies found that out-of-pocket health spending was higher in the groups covered by this program, even when compared to higher-income populations with private medical insurance. [50]

- Colombia has also been plagued by underfunding of its subsidized POS component, as well as high rates of informal workers evading their health contributions. Insufficient funding has furthered health inequities [24]. This research has shown that, under these conditions, even with FOSYGA crosssubsidization it does not guarantee the adequate funding. [22]

- Mexico currently faces a $25 \%$ deficit in health spending. Appropriate funding for Seguro Popular would require resource pooling and cooperation between the states and central government. [14] Because of this deficit, Mexican President Lopez Obrador stressed the need for its transformation resembling the Instituto Mexicano de Seguros Sociales [the Social Security Institute]. Hence, in July 2019, Seguro Popularmoved into the Instituto de Salud para el Bienestar [Institute of Social Welfare], which will have its structure and governance mechanism funded by central mechanisms and provide coverage against catastrophic health expenditures. [51, 52].

UHC remains an important policy agenda for many LACs, where achieving UHC requires more than health system reforms and financial protection.[7, 53, 54] Given that LMICs cannot subsidize all of their healthcare expenditures, financial protection measures are needed to achieve UHC. These could be achieved by improving tax policies, such as including a mandatory contribution or by involving the private sector to support structural inefficiencies in healthcare, or through the provision of funds by external donors, if required.

Many LAC continue to develop new initiatives in their quest for UHC. Prioritized health services baskets (benefits packages), selects healthcare interventions that demonstrate cost-effectiveness and might improve the UHC index by expanding access to high-value health services, while reducing the patient's financial burden. This methodology could be applied to prioritize essential services for other countries, as the Regimen de Garantias Esplicitas en Salud [Regime of Specific Guarantees in Health] program, or AUGE, in Chile did, and as it has been done in other LMICs. $[6,55,56]$ Chile's AUGE is a worthy example for 
LAC. AUGE offers both an extended benefits package and financial protection measures funded mainly through VAT taxes [57]. Moreover, in 2015, the Senate approved Ricarte Sotto bill, which created a fund to guarantee comprehensive care, including drugs, devices, and procedures for certain diseases not included in AUGE program.

Finally, strengthening PHC is a turnaround in health systems to commit to UHC and SDGs, as well as to include challenges posed by non-communicable diseases (cardiovascular disease, diabetes), as well as injuries, and emerging diseases with pandemic potential. $[4,6,53,58]$ This is an example of Argentina, that is expanding their PHC network at a wider scale allowing to maintain a continuum between the different levels of care.

In keeping with UHC aims, these following measures could be considered to enhance the health service delivery, while minimizing financial risk to patients:

- First, decentralize the PHC and transition their management to each region (community, municipality). To guarantee access to specialized healthcare services (i.e. surgical services or diagnostic tests) while avoiding excessive wait times, a referral program between the PHC and specialty care, usually run by the $\mathrm{MOH}$, should be available. Co-payments for the use of these centers need to be avoided.

- Second, find an efficient mechanism for the healthcare system financing, especially for the primary care. Channeling of funds from the central government to autonomous regions, conditional cash transfers, and implementation of "progressive" mechanisms for health expenditure have all been shown to be an efficient way to finance the PHC.[18] However, as the PAHO recommends allocating $30 \%$ of healthcare expenditure to PHC, coordination between finance and health authorities is required since political and economic instability faced by many countries in LAC might challenge the implementation of this recommendation.[59]

- Third, involving private organizations could be considered in countries with healthcare system structural or technical issues that may conflict the UHC. In the case of Southern Africa where private organizations were contracted to deliver PHC [60], or in Brazil where established agreements with NGOs to provide human resources for the first level of care, are such examples. [29] This requires that $\mathrm{MOH}$ controls the private sector performance with an outcomes-based approach. Healthcare governance with clear roles and responsibilities is required to guarantee that healthcare is being delivered equitably.

\section{LIMITATIONS}

The qualitative analysis of this project includes semi-structured surveys and policymakers from the region, supplements elements gathered from the literature synthesis. Semi-structured self-surveys are a direct way to collect information easily, but are plagued by low response rates. [61] Due to the extensive nature of these surveys, which could limit response rates, only three stakeholders per country were included in this analysis, making the data analysis more descriptive rather than quantitative; the low 
response rate was a primary limitation with this approach. Also, as a qualitative method, interview responses should not be extrapolated or compared with the level of certainty of other methods (i.e. quantitative analysis). An alternative to collect data more directly would have been to interview theses stakeholders by phone. Although this is a straightforward approach, the institutional written consent required would increase the time required to conduct and analyze these surveys.

\section{Conclusions}

This review presents the current situation of UHC implementation in Argentina, Brazil, Colombia, and Mexico, using different elements from the WHO in their 13th Program of Work to compare service coverage and financial protection. The four countries have made progress in the service coverage by implementing primary care reforms, and by incorporating of certain elements into their national health programs, such as subsidized essential medicines. However, these countries lag in providing strong financial protections from high medical bills based on WHO's global figures. While no country has achieved true UHC for all its citizens, UN member countries must develop the capabilities and strategies to achieve UHC if they are to meet WHO's goal of covering two billion people by 2030 .

Future targets for health system development in LAC include developing a sustainable PHC network (integrated health services networks) that would be capable of reaching more than $85 \%$ of the population at need.[59] Comprehensive health services includes family physicians and community healthcare workers as cornerstones of care, complemented with the provision of essential medicines, and access to childhood immunization programs. Non-communicable diseases prevention programs and the enhancement of social protection mechanisms are examples of strengthening PHC while providing financial protection.

\section{List Of Abbreviations}

AUGE: Acceso Universal con Garantias Explicitas (Chile)

CNPSS: Comision Nacional de Proteccion Social en Salud (Mexico)

EPS: Empresa Prestadora de Salud (Colombia)

ESF: Estrategia Saúde Familiar (Brazil)

FOSYGA: Fondo Solidario y de Garantias (Colombia)

GDP: Gross Domestic Product

HIS: Health Information Systems

HIV/AIDS: Human Immunodeficiency Virus 
IPS: Instituciones Prestadoras de Salud (Colombia)

ISB: Instituto de salud para el bienestar (Mexico)

LAC $\cdot$ Latin America and the Caribbean

LMICs: Low to middle-income countries

LSHTM: London School of Hygiene and Tropical Medicine

MoH: Ministry of Health

NCD: Non-Communicable Diseases

NGOs: Non-Government Organizations

PAHO: Pan American Health Organization

PCCs: Primary Care Centers

PHC: Primary Health Care

POS: Plan Obligatorio de Salud (Colombia)

PPP: Public-Private Partnerships

REPS: Regimenes de proteccion en salud (Mexico)

SDG: Sustainable Development Goals

SESA: Servicios Estatales en Salud (Mexico)

SHS: Suplementar Health Subsector (Brazil)

SMNG: Seguro Medico para la Nueva Generacion (Mexico)

SP: Seguro Popular (Mexico)

SUS: Sistema Único de Saúde (BRAZIL

UHC: Universal health coverage

WHO: The Wold Health organization

\section{Declarations}

Author's do not declare conflict of interest. 
No external source of funding for conducting the research or publication.

Authors Contribution: RG designed the aims and objectives of the research, conducted the literature review and the stakeholder's surveys. PV supported the literature review and evidence assessment. SR provided guidance through the entire project. All authors contributed equally drafting the manuscript.

Acknowledgements: We acknowledge Michele Cleary, PhD for providing editing services of the manuscript.

\section{References}

1. Atun R, de Andrade LOM, Almeida G, Cotlear D, Dmytraczenko T, Frenz P, et al. Health-system reform and universal health coverage in Latin America. Lancet. 2015;385:1230-47. doi:10.1016/S01406736(14)61646-9.

2. World Health Organization. WHO | Health Financing for universal coverage. World Health organization. 2015. https://www.who.int/health_financing/strategy/dimensions/en/. Accessed 11 Apr 2019.

3. World Health Organization. Sustainable Development Goal 3: Health. World Health Organization. 2016. https://www.who.int/sdg/targets/en/. Accessed 17 Jan 2020.

4. Rubinstein A, Barani M, Lopez S, Lopez AS. Quality first for effective universal health coverage in lowincome and middle-income countries. Lancet Glob Heal. 2018;6:e1142-3. doi:10.1016/S2214109X(18)30447-9.

5. Kluge H, Kelley E, Barkley S, Theodorakis PN, Yamamoto N, Tsoy A, et al. How primary health care can make universal health coverage a reality, ensure healthy lives, and promote wellbeing for all. Lancet. 2018;392:1372-4. doi:10.1016/S0140-6736(18)32482-6.

6. Watkins DA, Jamison DT, Mills A, Atun R, Danforth K, Glassman A, et al. Universal Health Coverage and Essential Packages of Care. In: Disease Control Priorities: Improving Health and Reducing Poverty. 3rd edition. Washington, DC.: The International Bank for Reconstruction and Development / The World Bank; 2017. http://www.ncbi.nlm.nih.gov/pubmed/30212154.

7. Erondu NA, Martin J, Marten R, Ooms G, Yates R, Heymann DL. Building the case for embedding global health security into universal health coverage: a proposal for a unified health system that includes public health. Lancet. 2018;392:1482-6. doi:10.1016/S0140-6736(18)32332-8.

8. Frenk J. Leading the way towards universal health coverage: a call to action. Lancet. 2015;385:1352-8. doi:10.1016/S0140-6736(14)61467-7.

9. Stigler FL, Macinko J, Pettigrew LM, Kumar R, van Weel C. No universal health coverage without primary health care. Lancet. 2016;387:1811. doi:10.1016/S0140-6736(16)30315-4.

10. Wagstaff A, Dmytraczenko T, Almeida G, Buisman L, Hoang-Vu Eozenou P, Bredenkamp C, et al. Assessing Latin America's Progress Toward Achieving Universal Health Coverage. Health Aff. 2015;34:1704-12. doi:10.1377/hlthaff.2014.1453. 
11. Okungu V, Chuma J, Mclntyre D. The cost of free health care for all Kenyans: assessing the financial sustainability of contributory and non-contributory financing mechanisms. Int J Equity Health. 2017;16:39. doi:10.1186/s12939-017-0535-9.

12. World Health Organization. SEVENTY-FIRST WORLD HEALTH ASSEMBLY: Draft thirteenth general programme of work, 2019-2023 - Report for Director General. Geneva; 2018. http://www.who.int/about/what-we-do/gpw13-expert-group/en/.

13. Cotlear D, Gómez-Dantés O, Knaul F, Atun R, Barreto ICHC, Cetrángolo O, et al. Overcoming social segregation in health care in Latin America. Lancet. 2015;385:1248-59. doi:10.1016/S01406736(14)61647-0.

14. González-Block MÁ, Figueroa A, García-Téllez I, Alarcón J. Asignación financiera en el Sistema de Protección Social en Salud de México: Retos para la compra estratégica [Financial allocations in the System for Social Protection in Health in Mexico: challenges for strategic purchasing]. Salud Publica Mex. 2016;58:522-32.

15. Hone T, Rasella D, Barreto ML, Majeed A, Millett C. Association between expansion of primary healthcare and racial inequalities in mortality amenable to primary care in Brazil: A national longitudinal analysis. PLOS Med. 2017;14:1-19. doi:10.1371/journal.pmed.1002306.

16. França GVA, Restrepo-Méndez MC, Maia MFS, Victora CG, Barros AJD. Coverage and equity in reproductive and maternal health interventions in Brazil: impressive progress following the implementation of the Unified Health System. Int J Equity Health. 2016;15:149. doi:10.1186/s12939016-0445-2.

17. Macinko J, Harris MJ. Brazil's Family Health Strategy - Delivering Community-Based Primary Care in a Universal Health System. N Engl J Med. 2015;372:2177-81. doi:10.1056/NEJMp1501140.

18. Rubinstein A, Zerbino MC, Cejas C, López A. Making Universal Health Care Effective in Argentina: A Blueprint for Reform. Heal Syst Reform. 2018;4:203-13. doi:10.1080/23288604.2018.1477537.

19. Chiara M, Crojethovic M, Ariovich A. El universalismo en salud en Argentina entre 2003 y 2015 : Balances y desafíos desde una aproximación macroinstitucional. Salud Colect. 2017;13:663-76.

20. Barreto ML, Rasella D, Machado DB, Aquino R, Lima D, Garcia LP, et al. Monitoring and Evaluating Progress towards Universal Health Coverage in Brazil. PLoS Med. 2014;11:e1001692. doi:10.1371/journal.pmed.1001692.

21. Muzaka V. Lessons from Brazil: on the difficulties of building a universal health care system. J Glob Health. 2017;7:1-5. doi:10.7189/jogh.07.010303.

22. Uribe-Gómez M, Uribe-Gomez M. Nuevos cambios, viejos esquemas: las políticas de salud en México y Colombia en los años 2000. Cad Saude Publica. 2017;33 suppl 2:e00112616. doi:10.1590/0102$311 \times 00112616$.

23. Laurell AEC. Competing health policies: insurance against universal public systems. Rev Lat Am Enfermagem. 2016;24:e2668. doi:10.1590/1518-8345.1074.2668.

24. Amaya JL, Ruiz F, Trujillo AJ, Buttorff C, Library WO. Identifying barriers to move to better health coverage: preferences for health insurance benefits among the rural poor population in La Guajira, 
Colombia. Int J Health Plann Manage. 2016;31:126-38. doi:10.1002/hpm.2268.

25. Abeldaño RA. Análisis del gasto de los hogares en salud en Argentina, como componente de la cobertura universal de salud. Cien Saude Colet. 2017;22:1631-40. doi:10.1590/141381232017225.21102015.

26. Machado CV. Políticas de Saúde na Argentina, Brasil e México: diferentes caminhos, muitos desafios. Cien Saude Colet. 2018;23:2197-212. doi:10.1590/1413-81232018237.08362018.

27. Chieffi AL, Barradas RDCB, Golbaum M. Legal access to medications: a threat to Brazil's public health system? BMC Health Serv Res. 2017;17:499. doi:10.1186/s12913-017-2430-x.

28. Monteiro CN, Gianini RJ, Barros MB de A, Cesar CLG, Goldbaum M. Access to medication in the Public Health System and equity: populational health surveys in São Paulo, Brazil. Rev Bras Epidemiol. 2016;19:26-37. doi:10.1590/1980-5497201600010003.

29. Greve J, Schattan Ruas Pereira Coelho V. Evaluating the impact of contracting out basic health care services in the state of São Paulo, Brazil. Health Policy Plan. 2017;32:923-33. doi:10.1093/heapol/czw176.

30. Campos GW de S. SUS: o que e como fazer? Cien Saude Colet. 2018;23:1707-14. doi:10.1590/141381232018236.05582018.

31. Belló M, Becerril-Montekio VM. Sistema de salud de Argentina. (Spanish). Salud Publica Mex. 2011;53:S96-108.

32. Ventura CAA, Junior RC, Gutier MS, Mendes IAC. Alternatives for the enforcement of the right to health in Brazil. Nurs Ethics. 2016;23:318-27. doi:10.1177/0969733014562991.

33. Garrafa V, Cunha TR DA, Manchola C. Access to Healthcare: A Central Question within Brazilian Bioethics. Cambridge Q Healthc Ethics. 2018;27:431-9. doi:10.1017/S0963180117000810.

34. Campbell J, Buchan J, Cometto G, David B, Dussault G, Fogstad H, et al. Human resources for health and universal health coverage: fostering equity and effective coverage. Bull World Health Organ. 2013;91:853-63. doi:10.2471/BLT.13.118729.

35. Santos LMP, Oliveira A, Trindade JS, Barreto IC, Palmeira PA, Comes Y, et al. Implementation research: towards universal health coverage with more doctors in Brazil. Bull World Health Organ. 2017;95:103-12. doi:10.2471/BLT.16.178236.

36. Mathauer I, Behrendt T. State budget transfers to Health Insurance to expand coverage to people outside formal sector work in Latin America. BMC Health Serv Res. 2017;17:145. doi:10.1186/s12913-017-2004-y.

37. Chemor Ruiz A, Ratsch AEO, Alamilla Martínez GA. Mexico's Seguro Popular: Achievements and Challenges. Heal Syst Reform. 2018;4:194-202. doi:10.1080/23288604.2018.1488505.

38. Gutiérrez JP, Hernández-Ávila M. [Health protection coverage in Mexico, and profile of unprotected population 2000-2012]. Salud Publica Mex. 2013;55 Suppl 2:S83-90. http://www.ncbi.nIm.nih.gov/pubmed/24626718. 
39. Servan-Mori E, Heredia-Pi I, Montañez-Hernandez J, Avila-Burgos L, Wirtz VJ. Access to Medicines by Seguro Popular Beneficiaries: Pending Tasks towards Universal Health Coverage. PLoS One. 2015;10:e0136823. doi:10.1371/journal.pone.0136823.

40. Ministerio de Salud A. Remediar | . https://www.argentina.gob.ar/salud/remediar. Accessed 13 May 2020.

41. Vélez M, Wilson MG, Abelson J, Lavis JN, Paraje G. Understanding the role of values in health policy decision-making from the perspective of policy-makers and stakeholders: A multiple-case embedded study in Chile and Colombia. Int J Heal Policy Manag. 2020;9:185-97. doi:10.15171/ijhpm.2019.94.

42. Gómez-Dantés O, Wirtz V, Reich M, Terrazas P, Ortiz M. A new entity for the negotiation of public procurement prices for patented medicines in Mexico. Bull World Health Organ. 2012;90:788-92. doi:10.2471/BLT.12.106633.

43. Juan M. [Towards a National Universal Health System]. Cir Cir. 2014;82:98-108. http://ovidsp.ovid.com/ovidweb.cgi?T=JS\&PAGE=reference\&D=medc\&NEWS=N\&AN=25647852.

44. Azuara O, Marinescu I. Informality and the expansion of social protection programs: Evidence from Mexico. J Health Econ. 2013;32:938-50. doi:10.1016/j.jhealeco.2013.07.004.

45. Martínez G. Política de asignación de recursos del Seguro Popular: Análisis y recomendaciones. Salud Publica Mex. 2016;58:577-83.

46. Machado CV, Lima LD de, Baptista TW de F. Políticas de saúde no Brasil em tempos contraditórios: caminhos e tropeços na construção de um sistema universal. Cad Saude Publica. 2017;33 suppl 2:S143-62. doi:10.1590/0102-311 x00129616.

47. Figueroa-Lara A, González-Block MÁ. Costo-efectividad de una alternativa para la prestación de servicios de atención primaria en salud para los beneficiarios del Seguro Popular de México. Salud Publica Mex. 2016;58:569-76.

48. Urquieta-Salomón JE, Villarreal HJ. Evolution of health coverage in Mexico: evidence of progress and challenges in the Mexican health system. Health Policy Plan. 2016;31:28-36. doi:10.1093/heapol/czv015.

49. Castro MC, Massuda A, Almeida G, Menezes-Filho NA, Andrade MV, de Souza Noronha KVM, et al. Brazil's unified health system: the first 30 years and prospects for the future. Lancet. 2019;394:34556. doi:10.1016/S0140-6736(19)31243-7.

50. Cataife G, Courtemanche $C$. Income-based disparities in health care utilisation under universal health coverage in Brazil, 2002-2003. Glob Public Health. 2014;9:394-410. doi:10.1080/17441692.2014.891631.

51. Martinez M del P. Seguro Popular centralizará gasto y ampliará coberturas. El Economista. 2019. https://www.eleconomista.com.mx/empresas/Seguro-Popular-centralizara-gasto-y-ampliaracoberturas-20190417-0021.html. Accessed 10 May 2019.

52. Astrid R. Que pasara tras la eliminacion del Seguro Popular? El Universal. 2019.

53. Wang $\mathrm{H}$, Torres LV, Travis P. Financial protection analysis in eight countries in the WHO South-East Asia Region. Bull World Health Organ. 2018;96:610-620E. doi:10.2471/BLT.18.209858. 
54. Shroff ZC, Rao KD, Bennett S, Paina L, Ingabire M-G, Ghaffar A. Moving towards universal health coverage: engaging non-state providers. Int J Equity Health. 2018;17:135. doi:10.1186/s12939-0180844-7.

55. Glassman A, Giedion U, McQueston K. Priority setting for health in emerging markets. J Comp Eff Res. 2013;2:283-91. doi:10.2217/cer.13.12.

56. Chalkidou K, Glassman A, Marten R, Vega J, Teerawattananon Y, Tritasavit N, et al. Priority-setting for achieving universal health coverage. Bull World Health Organ. 2016;94:462-7. doi:10.2471/BLT.15.155721.

57. Vega J, Frenz P. Latin America: priorities for universal health coverage. Lancet. 2015;385:e31-2. doi:10.1016/S0140-6736(14)61635-4.

58. The World Bank. World Bank Country and Lending Groups. 2019. https://datahelpdesk.worldbank.org/knowledgebase/articles/906519-world-bank-country-andlending-groups. Accessed 30 Oct 2018.

59. Pan American Health Organization. "Universal Health in the 21 st Century: 40 Years of Alma-Ata"; Report of the High-Level Commission. Washington, DC; 2019. https://reliefweb.int/sites/reliefweb.int/files/resources/9789275120682_eng.pdf. Accessed 9 Aug 2019.

60. Whyle EB, Olivier J. Models of public-private engagement for health services delivery and financing in Southern Africa: a systematic review. Health Policy Plan. 2016;31:1515-29. doi:10.1093/heapol/czw075.

61. Gale NK, Heath G, Cameron E, Rashid S, Redwood S. Using the framework method for the analysis of qualitative data in multi-disciplinary health research. BMC Med Res Methodol. 2013;13:117. doi:10.1186/1471-2288-13-117.

\section{Figures}




\section{Health Service Delivery}

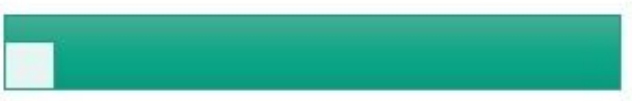

Primary Healthcare implementation

Sexual and Reproductive programs in place?

Diseases management program (NCD / CD)

Quality of care programs implementation
Access to medicine and Health Products

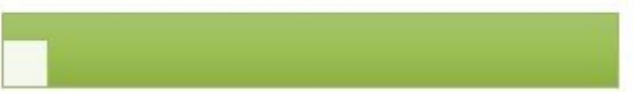

Implementation of extended vaccination programs

Access to generic medicines tackling most relevant health issues

Implementation of Health Technology Assessment

Regulations for safer access to blood products

Provide extended coverage for TB, Malaria and zoonoses

\section{Governance, Finance, stewardship and HIS}

Provide a legal framework for $\mathrm{HC}$ service implementation

Provide a framework for cooperation beyond borders

Provide a framework for cooperation within other state members

Public Private partnerships implementation to support UHC

Disease registries implementations

National statistics in place

Evidence based healthcare programs

Implementation of telemedicine to support access to healthcare

\section{Figure 1}

Characteristics of the evidence assessment matrix 


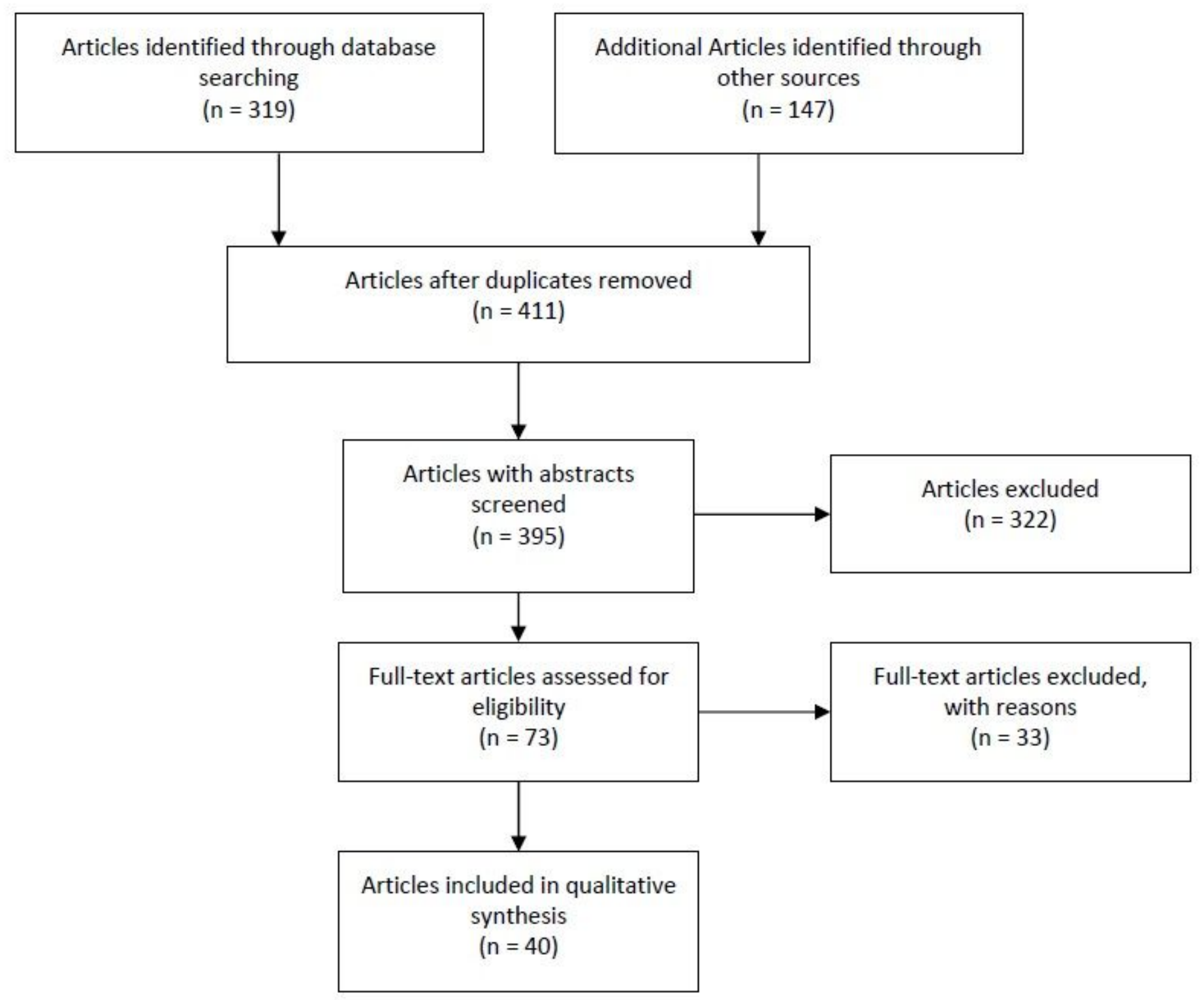

Figure 2

Prisma Flow diagram from literature search

\section{Supplementary Files}

This is a list of supplementary files associated with this preprint. Click to download.

- UHCLASupplementaryMaterial.pdf 